\title{
A Study on the Imbalance between the Supply and Demand of Rural Financial Market and Its Development Strategies
}

\author{
Hongman Guo \\ Zhengzhou Institute of Technology, Zhengzhou City, Henan Province, \\ 450044, China
}

\begin{abstract}
Rural financial market plays an important role in promoting the sustainable development of rural economy. However, at present, China's rural economic development started late and the income level of farmers is growing slowly. This paper argues that the main reason for the slow rural development and low income level is the financial restraint. In other words, the imbalance between the supply and demand cannot play the functions of rural finance. Based on the author's learning and practical experience, this paper first analyzed the specific manifestation of rural financial market imbalance, and then studied the causes of this imbalance. Finally the article proposed development strategies to balance the rural financial market in China.

Keywords: Rural finance; Imbalance between supply and demand; Causes; Development countermeasures

\section{Introduction}

As an important fulcrum of the construction of new socialist countryside, the construction and development of rural financial market plays an important role. However, the contradiction between the supply and demand of rural financial market is prominent and there exists serious financial repression. To solve the contradiction between the supply and demand in rural financial market, it is necessary to build a rural financial system in line with rural financial needs[1]. The reform of the rural financial system plays an important role in the
\end{abstract}


construction of the basic institutional framework of China's rural financial market and the improvement of rural supply and demand. However, the current supply and demand of rural finance is still in short supply seriously. The current situation of the rural financial market has seriously hindered the development of the rural economy. In order to ensure the rational development of the rural economy, it is necessary to analyze the rural financial market and find the effective reform plan.

\section{The Specific Manifestation of Rural Financial Market Imbalance}

\subsection{The characteristics of rural financial market supply}

First, the number of the suppliers reduces and the function weakens. With the gradual withdrawal of non-agricultural financial institutions from rural areas, the main suppliers in rural financial market include the Agricultural Development Bank, Agricultural Bank of China and Rural Credit Cooperatives. Agricultural Development Bank is a policy bank and its role is limited to strengthen the enclosed management of grain and oil purchasing fund. In other words, this bank is fixed in the circulation of the rural economy and it plays little role in the production of rural economy. With the marketization of the acquisition of grain and oil, the position of the Agricultural Development Bank which supports agriculture is weakening. As a traditional professional agriculture-related bank, the Agricultural Bank of China has always been the main force to support agriculture in the financial field[2].

Second, there is a serious outflow of rural funds and the supply is limited. The serious outflow of funds in China's rural financial market causes a serious shortage of rural capital supply. First of all, the special institution of postal savings which just conduct deposit business without loan transactions has become the main channel for rural capital loss. Rural Credit Cooperatives have weak financial strength and their supporting agricultural funds can not meet the needs of farmers. In order to better support the supporting agriculture work of credit cooperatives, the People's Bank of China has provided some loan for Rural Credit Cooperatives in recent years, but it is difficult to be a strong backing for Rural Credit Cooperatives with the limited funds.

Third, the rural financial market develops slowly and the financial instrument is single with scarce credits types. Compared with financial markets in developed countries, the type, quantity and corresponding financed amount of financial instruments in China are insufficient. In the rural financial market, the treasury bonds, especially book-entry treasury bonds are rarely issued in rural areas. The main financial instruments are the bank deposits. It is difficult for durable consumer goods loans, travel loans and other financial new business to enter the rural market, not alone the insurance, securities and other agents business. 


\subsection{The characteristics of rural financial market demand}

First, demand subjects and structures are diversified. At present, the rural economy realizes the strategic structural adjustment. The demand for rural capital is no longer limited to the general farmers. The large specialized-households of crops or animals, all kinds of individual businesses, township enterprises and basic-level governments all need capital support[3]. With the development of rural economy, the demand for financial services in rural areas has changed from living capital needs to operating capital needs.

Second, the individual needs are personalized. In rural areas, there are many main financial subjects, such as rental farmers, small-scale farmers, large-scale farmers, farmers who are engaged in non-agricultural individual economy and private owners. The demand of self-employed farmers is the deposit demand; large-scale farmers need short-term productive loan and agricultural production insurance; rental farmers demand for deposits and non-agricultural business loans; individual private owners need short-term business loans.

Third, the demand for financial instruments is diversified. In recent years, with the continuous development of rural economy, the employment structure of rural residents has changed greatly. Part-time businesses, export of labor service and inter-region flow increase. Therefore, farmers have diversified demand of financial services. They not only need working capital, but also need long-term investment capital. Besides, they need credit services and other intermediary services, including exchange, settlement, custody, transfer, consulting and agency. However, the rural financial institutions just provide single financial services and lack electronic financial products and financial innovation, so that the contradiction between the supply and demand of rural financial services is prominent.

\section{The Causes of Rural Financial Market Imbalance}

\subsection{Institution constraint}

China's rural financial system reform is a compulsory institutional change driven by the government's administrative power, and the main body of the reform is the government rather than farmers. Each reform is the embodiment of the will of the government. As subjects of rural financial needs, farmers have become spectators in the reform. At the same time, the reform focuses on stock and pays little attention to increment, which causes the absence of the original supply subjects. The new financial institutions can not timely follow the demand, which results in a serious shortage of financial products in rural areas[4].

\subsection{Mechanism constraint}

The reform of financial system in rural areas attaches importance to external 
reform and neglects the internal improvements of rural financial institutions, which results in rigid operating mechanism, backward financial service means and low service level. First, the credit authority is highly centralized and the loan autonomy of the primary financial institutions that are close to the rural economy is too small. For example, the loan authority of Rural Credit Cooperatives is too low and it needs approval at all levels to issue large loans. The process is complicated with various procedures. Second, the financial services means are backward and there is a lack of products. Rural financial institutions, especially Rural Credit Cooperatives still conduct the traditional deposit-based business and the development of high-tech notes, electronic remittance, bank cards and other new business has not yet established or are just in the initial stage. They lack smooth top-down clearing channels, which has a serious impact on the service level of rural financial institutions.

\subsection{Policy constraint}

At present, the policy of higher deposit interest rate on postal savings makes postal savings transfer funds from rural areas to urban areas with unfair competition, but regulators can not put forward effective solutions. At the same time, they neglect fund demand of agricultural leading enterprises and rural economic organizations. In addition, after the establishment of non-state-owned rural financial organizations, the urban and rural areas have different policies. Therefore, strict financial control policies affect the effective supply of financial organizations and increase opportunities for the rural capital outflow.

\section{Development Strategies to Balance the Rural Financial Market in China}

\subsection{To loosen the entry of rural financial market and build a diversified financial service system}

First of all, it is necessary to loosen entry conditions of the rural financial market for the emerging commercial banks and joint-stock commercial banks to open and develop the rural capital market[5]. The government should allow the private capital to enter the rural financial sector to form a diversified rural financial system, so as to promote the competition in rural financial market and meet various financial needs in rural areas. Second, the government should deepen the reform of Rural Credit Cooperatives to give full play to Rural Credit Cooperatives in supporting agriculture in order to ensure that its funds are really used for the specified purposes. Meanwhile, the government should allow them to expand the scope of policy-related business to support the construction of rural infrastructure and water conservancy.

4.2 To regulate the institutional environment for informal financial development and promote informal financial development

China should loosen financial control, strengthen the innovation of informal 
financial system, standardize informal financial organizations and establish the multilevel non-governmental financial organization system. Financial regulatory authorities should make financial system arrangements for informal finance, provide business guidance, standardize market withdrawal mechanism and dissolve financial risks[6]. Besides, they should strengthen the monitoring of informal financial interest rates to prevent illegal fund and financial fraud. Moreover, these authorities need regular supervision of the operation mechanism, the borrowers and lenders, interest rates and capital investment of informal finance to reduce risk.

\subsection{To establish the fund inflow mechanism to reduce the capital diversion in rural areas}

The government need to take feasible measures to prevent rural capital outflows and expand the scale of rural credit. Through the financial discount, the government should guide the credit funds to invest in rural areas, regulate financial services of major commercial banks in rural areas and gradually abolish branches which just conduct deposit service. The government should take some preferential tax measures of agriculture-related loans interest of commercial banks, adjust the function of rural postal saving and establish the fund inflow mechanism. Moreover, postal savings should nurture the rural areas in the form of agricultural re-loan of People's Bank of China. Besides, the government should improve the floating range of the rural loan interest rate, enhance the reform of rural credit cooperative property rights and reduce rural capital diversion[7].

\subsection{To implement premium subsidies and develop agricultural insurance}

According to the level of agricultural economic development, the central and local finance should take a certain percentage share from the financial funds as the insurance premium subsidies to support the Chinese reinsurance companies to assume the national agricultural reinsurance function. In addition, the government should set up a special management institution for catastrophe risk funds to share certain risks of the agricultural insurance agencies. In other words, agricultural insurance is mainly run by the government directly, or the government commissions insurance companies. Insurance companies just charge management fees and they do not charge premiums. They provide services with low premiums and high security. The government should gradually establish an agricultural and rural insurance system with multilevel system, multiple channels and multiple subjects to vigorously develop agricultural insurance.

\subsection{To increase support for rural financial institutions with corresponding policies}

Due to the small scale and decentralization of production and operation of rural households, the financial services are expensive and risky. Therefore, the government should appropriately reduce business tax and income tax of rural financial organizations that provide financial services to farmers, regardless of 
their forms and sizes. Besides, the government should exempt tax of loans to farmers and make some policies to encourage and support these institutions.

\section{Conclusion}

At present, the development of China's rural financial market is confronted with many problems caused by complex systems and policies. It is unrealistic to just rely on the reform of Rural Credit Cooperatives to change the entire rural financial system. Therefore, we must speed up the innovation of the whole rural financial market system, promote the reform of the rural financial system with reasonable division of labor and complementary functions, coordinate the balanced development of rural finance and economy, and improve the macroeconomic environment of rural finance.

\section{Reference}

[1] Li Yabin, Liu Ying and Zhang Ruijue. A Study on the Supply and Demand of China's Rural Financial Market and Marketing Strategies. Journal of Kunming Metallurgy College, (02), pp.69-73, 2016.

[2] Wang Tianqi. A Literature Review of China's Rural Financial Research. Modern Economic Information, (02), pp.328-329, 2015.

[3] Cao Liang. The Supply and Demand Analysis of Rural Financial Market. Managers' Journal, (02), pp.88, 2015.

[4] Zong Jie, Jiao Jiang. A Discussion on Causes and Countermeasures of the Imbalance between the Supply and Demand in China's Rural Finance. Theoretical Investigation, (04), pp.168-170, 2014.

[5] Yin Shuai. An Analysis of the Supply and Demand Contradiction and Its Causes in China's Rural Financial Market. Journal of Jilin Financial Research, (06), pp.28-32, 2013.

[6] Dang Mingcan. An Empirical Analysis of the Imbalance between the Supply and Demand of Rural Finance in Henan Province. Journal of Management, (04), pp.26-29, 2010.

[7] Liao Shun. A Research of the Supply and Demand Contradiction of China's Rural Finance and Its Countermeasures. Chinese and Foreign Entrepreneurs, (04), pp.116-118, 2009. 